\title{
An Imperfect Integration: Has Schengen Alienated Europe?
}

\author{
Shichen Wang ${ }^{1}$ (D)
}

Received: 30 April 2016/Accepted: 12 August 2016/Published online: 19 August 2016

(C) Fudan University and Springer Science+Business Media Singapore 2016

\begin{abstract}
The Schengen Agreement is widely regarded as one of the greatest achievements of internal integration by the European Union. Free movement of people, goods, and capital in the Schengen Area is a great experiment in the whole history of human kind. However, not all of the European Union Member States are involved, or totally involved in this process. Some countries like the UK and Ireland chose to opt out. Other countries which newly joined the EU like Romania, Bulgaria, and Croatia are still striving to meet all the conditions. Even within the Schengen states, old states and new states have different authorities in several aspects such as visa policies. The Schengen Agreement is helping the European integration. However, different states have chosen different relationships with it and caused three categories of states: associated Schengen State, new Schengen State, and semi-Schengen State. Therefore, Schengen is an "imperfect integration" caused by differentiation. The purpose of Schengen is to unite European countries. However, it alienated some countries from others.
\end{abstract}

Keywords European Union · Schengen · European integration · Differentiation

\section{Introduction}

During the half-century long European integration since the Schuman Plan in 1950, the European Union (EU) has witnessed many historical agreements and events, among which the Schengen Agreement is widely regarded as one of the most influential integration methods and praised not only within the EU but also

Shichen Wang

chamberlainwang@hotmail.com

1 Université libre de Bruxelles and University of Geneva, Sciences II, 30, Quai Ernest-Ansermet, 1211 Geneva, Switzerland 
worldwide (Anderson and Bort 2001; Keukeleire and Tom 2014a). Free movement of people, goods, and capital inside the Schengen Area is a marvelous experiment in the whole history of Europe (Brady 2008). Nowadays, not only can citizens of EU member states enjoy free movement in the Schengen Area, but visitors from outside the EU can also benefit from the convenience brought by the Schengen acquis.

However, not all of the European countries are involved, or totally involved in this process (Smith 2011). Some countries like the United Kingdom (UK) and Ireland chose to opt out, which means means they remain outside of the Schengen Area and maintain their border controls. ${ }^{1}$ Newly joined EU member states like Romania, Bulgaria, and Croatia are still striving to meet all the conditions of the Schengen headquarters and have not yet been approved to become Schengen states. ${ }^{2}$ Even within the Schengen states, old states and new states have different authorities in several aspects, such as visa policies. These cause debates and arguments from different parties, which make Schengen not a completely harmonious integration of Europe (Kolliker 2001).

This study argues that the Schengen Area is an imperfect integration of the EU. What is a perfect integration? This idea was used by Gustavo Flores-Macias to describe the Northern America Free Trade Agreement (NAFTA), which was an "imperfect integration" from his perspective (Flores-Macias 2007). Flores-Macias argues that the NAFTA is not fully functioning in practice. If the US, Canada, and Mexico cooperate better, the NAFTA could achieve a higher level of economic integration. This study borrows this idea and applies it to examine the Schengen. According to the EU, all citizens inside should enjoy free movement and resettlement inside the EU. ${ }^{3}$ In addition, visitors should have equal visa policies when they apply for visas at each EU member state's embassies and consulates. Yet, the reality is quite different. With several member states opting out of the Schengen agreement as well as various visa policies and practices at different member states, the Schengen Area has not achieved the result that the original blueprint planned. Therefore, the Schengen Area cannot be regarded as a perfect integration. However, although problems still exist, the Schengen Area has no doubt played a positive role in accelerating European integration. The economic growth of the EU, the establishment of the Eurozone, and the world renowned Erasmus student exchange program have all benefited from the Schengen Area. An imperfect integration is a proper title for the Schengen Area.

Therefore, it is necessary to evaluate the impact of Schengen on European integration. As an imperfect integration, how has Schengen affected European integration in the past three decades? Inside the EU, different member states have different relations with the Schengen Area. Outside the EU, how do Switzerland,

\footnotetext{
${ }^{1}$ 2004. Council Decision (2004/926/EC) of 22 December 2004 on the putting into effect of parts of the Schengen acquis by the United Kingdom of Great Britain and Northern Ireland. European Council.

2 2013. Report from the Commission to the European Parliament and the Council-Third Biannual Report on the Functioning of the Schengen Area (1 November 2012-30 April 2013). European Commission. http://ec.europa.eu/dgs/home-affairs/doc_centre/borders/docs/third_biannual_report_on_ the_functioning_of_the_schengen_area_en.pdf.

${ }^{3}$ European Commission Home Affairs: Schengen Area. http://ec.europa.eu/dgs/home-affairs/what-wedo/policies/borders-and-visas/schengen/index_en.htm.
} 
Norway, and other European countries manage the relationship with the Schengen Area? Outside Europe, what is the influence of Schengen on other countries? The key question of this study is whether has Schengen alienated Europe, and if so how has it achieved that? One thing that needs to be pointed out is that the term "European integration" here is not only referring to the integration initiated by or within the EU framework but rather the whole integration process of the European continent including those countries not in the EU as well as those who are or will apply to join the EU. In short, it is an overall perspective on the integration of European countries.

This study includes four parts. The first part introduces the Schengen Agreement and its development, and will review the founding of the Schengen Area and its enlargements in the past two decades. Also, the relationship between the EU and the Schengen states will be clarified. The second part is entitled "Differentiated Integration." The Schengen Agreement is no doubt helping European integration. However, different states have chosen different relationships with it and caused three categories of states: associated Schengen State, new Schengen State, and semiSchengen State. Their motivations and consequences will be analyzed. The third part is entitled "United or Alienated." Analysis will be developed according to three perspectives: Schengen states, non-Schengen states, and states outside of Europe. The argument of 'imperfect integration' will be raised followed by the conclusion.

\section{Schengen Agreement and its Development}

On June 14, 1985, the governments of Belgium, Germany, France, the Netherlands, and Luxembourg signed the Schengen acquis-Agreement between the Governments of the States of the Benelux Economic Union, the Federal Republic of Germany and the French Republic on the Gradual Abolition of Checks at their Common Borders, which is widely known as the Schengen Agreement nowadays, because the venue of the meeting was near the town of Schengen in Luxembourg. ${ }^{4}$

The Agreement is one of the most important documents in the history of the EU and its predecessor the European Community (EC). It gives "freedom to cross internal border for all nationals of these countries in the free movement of goods and services" as well as "strengthens the solidarity between their peoples by removing the obstacles to free movement at the common borders between the States of the Benelux Economic Union, the Federal Republic of Germany, and the French Republic." 5 The Schengen Convention supplemented the Schengen Agreement in 1990, which was a big step toward further European integration. According to the

\footnotetext{
4 June 15,1985. The Schengen acquis-Agreement between the Governments of the States of the Benelux Economic Union, the Federal Republic of Germany, and the French Republic on the gradual abolition of checks at their common borders. EUR-Lex. http://eur-lex.europa.eu/legal-content/EN/ALL/ ?uri=CELEX:42000A0922(01).

5 June 15, 1985. The Schengen acquis - Agreement between the Governments of the States of the Benelux Economic Union, the Federal Republic of Germany, and the French Republic on the gradual abolition of checks at their common borders. EUR-Lex. http://eur-lex.europa.eu/legal-content/EN/ALL/ ?uri=CELEX:42000A0922(01).
} 
Schengen Convention, all the internal borders between members states of Schengen Area should be abolished, while a common visa policy should be launched, which is known as the Schengen Visa nowadays. Along with the abolition of border controls and creation of a common visa policy, other kinds of cooperation between Schengen states were also initiated by the Schengen Convention, including in police and judicial areas (De Zwaan 1998).

After ratification by the five founding countries, the development of the Schengen Agreement can be divided into two periods. The first period is from 1985 to 1997 . The second period is from 1997 to the present. During the first period, the Agreement met quite a lot of obstacles in its development and enlargement. Since it was signed independently of the EC and lacked consensus among member states, it was regarded as a political creation or experiment by other member states inside the EC. It did not come into force until 1995 within the EU, already a decade after its signature. Even in the early years after the implementation of the Schengen Agreement, it was still considered as an intergovernmental cooperation agreement rather than a European agreement under the convention of the EC or EU. The second period started from the symbolic Amsterdam Treaty. During the Amsterdam Intergovernmental Conference, all the EU member states at that time, except the UK and Ireland, signed the Schengen Agreement. Meanwhile, the incorporation of the Schengen acquis into the main body of the EU law was agreed along with opt-outs for Ireland and the UK which chose to remain outside of the Schengen Area. Thus, after the Amsterdam Treaty, the Schengen acquis has been integrated into the EU (Avery 2012; Den Boer and Corrado 1999; Kuijper 2000).

Owning to the development of the European integration process, the Schengen Area has also been expanded after each enlargement of the EU, although some new member states cannot meet part of the requirements of a Schengen state and may need to wait until these conditions are satisfied (Keukeleire and Tom 2014b). Currently, there are 26 Schengen states, including 22 EU member states and 4 NonEU states which are Iceland, Liechtenstein, Norway, and Switzerland. Ireland and the UK are still not in the Schengen Area. In addition, there are four candidate states, Bulgaria, Cyprus, Croatia, and Romania, which joined the EU in recent years. The detailed countries list is showed in Table 1 with the year they joined the Schengen Area. The three European microstates, Monaco, Vatican, and San Marino can also be considered as de facto Schengen states, because they do not have any border control with those Schengen countries surrounding them.

The Schengen provisions abolish checks at the Union's internal borders, while tightening controls at the external borders, in accordance with a single set of rules. ${ }^{6}$ These rules cover several areas:

1. A common set of rules applying to people crossing the EU external borders, including the types of visa needed and how checks at external borders have to be carried out.

2. Harmonization of the conditions of entry and of the rules on visas for short stays (up to 3 months).

\footnotetext{
${ }^{6}$ Europe Commission Home Affairs: Schengen Area. http://ec.europa.eu/dgs/home-affairs/what-we-do/ policies/borders-and-visas/schengen/index_en.htm.
} 
Table 1 EU and Schengen States (until July 2013) Source: European Commission

\begin{tabular}{|c|c|}
\hline Status & Countries \\
\hline EU Schengen states & $\begin{array}{l}\text { Austria (1995), Belgium (1985), Czech Republic (2004), Denmark (1996), Estonia } \\
\text { (2004), Finland (1996), France (1985), Germany (1985), Greece (1992), } \\
\text { Hungary (2004), Italy (1990), Latvia (2004), Lithuania (2004), Luxembourg } \\
\text { (1985), Malta (2004), Netherlands (1985), Poland (2004), Portugal (1992), } \\
\text { Slovenia (2004), Slovakia (2004), Spain (1992), Sweden (1996) }\end{array}$ \\
\hline $\begin{array}{l}\text { Non-EU Schengen } \\
\text { states }\end{array}$ & Iceland (1996), Liechtenstein (2008), Norway (1996), Switzerland (2004) \\
\hline $\begin{array}{l}\text { Non-Schengen EU } \\
\text { states }\end{array}$ & Ireland, UK \\
\hline $\begin{array}{l}\text { Schengen candidate } \\
\text { states }\end{array}$ & Bulgaria, Croatia, Cyprus, Romania \\
\hline
\end{tabular}

3. Enhanced police cooperation (including rights of cross border surveillance and hot pursuit).

4. Stronger judicial cooperation through a faster extradition system and transfer of enforcement of criminal judgments.

5. Establishment and development of the Schengen Information System (SIS).

6. Documents needed for traveling in Europe.

Following the incorporation of the Schengen acquis into the EU framework, new EU member states are bound to join the Schengen Area. However, we can still find that EU member states, such as Cyprus, Romania, Bulgaria, and Croatia, are still out of the Schengen Area, because joining the Schengen Area is not merely a political decision. All the EU member states who want to join the Schengen Area should meet a list of preconditions, including the following:

1. Take responsibility for controlling the external borders on behalf of the other Schengen States and for issuing uniform Schengen visas.

2. Efficiently cooperate with law enforcement agencies in other Schengen states to maintain a high level of security once border controls between Schengen countries are abolished.

3. Apply the common set of Schengen rules (the so-called 'Schengen acquis'), such as controls of land, sea and air borders (airports), issuing of visas, police cooperation and protection of personal data.

4. Connect to and use the SIS.

Cyprus has been an EU member for about a decade but still has not met the conditions due to its conflict with Greece. As for Bulgaria, Romania, and Croatia, some other EU member states have concerns about migration after they become Schengen countries, since both of these two states have a relatively big population and may cause unemployment within the domestic labor force in other EU member states. ${ }^{7}$

\footnotetext{
7 2007. Evaluating Schengen. Royal United Services Institute (RUSI). https://rusi.org/publication/ evaluating-schengen.
} 


\section{Differentiated Integration}

It is obvious that the Schengen states have different status. Some are EU member states, while others are not. Meanwhile, some EU member states have opted out, such as the UK and Ireland. Therefore, the management of Schengen states has to be differentiated according to their status. According to the EU, Iceland, Liechtenstein, Norway, and Switzerland, the four non-EU Schengen states are recognized as "Associated Schengen State." 8,9 This study adds two more categories: the new Schengen State, which refers to EU Member States which joined after the Big Bang in 2004, and the semi-Schengen State, which refers to the UK and Ireland.

\subsection{Associated Schengen State}

Currently, there are four associated Schengen states: Iceland, Norway, Liechtenstein, and Switzerland. The first two countries together with the EU created this mechanism in the late 1990s, which provided Liechtenstein and Switzerland a possible solution to managing the relationship with the EU member states when they joined the Schengen Area in 2008. ${ }^{10}$

The Nordic Passport Union was founded by an agreement between four of the Nordic countries including Norway, Sweden, Denmark, and Finland. The agreement was signed on July 12, 1957. Iceland became a party to the agreement on September 24, 1965. Together with other Nordic countries, Iceland and Norway had already become members of the Schengen Area when the EU states decided to make cooperation in this area into part of the workings of the EU. It was after the declaration by the Nordic prime ministers in 1995 that the Nordic countries began negotiations on participation in the Schengen scheme, which, at that time, took the form of traditional international cooperation. Denmark had already applied for the status of an observer member of the Schengen. The five Nordic countries' had to make up their minds as to whether, and if so, how, they would continue with the Nordic Passport Union. If Denmark alone were to join the Schengen scheme without other Nordic countries, it would have meant that the outer borders of the Schengen area would have been drawn down through the Nordic countries, thus entailing the end of the Nordic Passport Union (Eiriksson 2006, pp. 50-58).

At that time, the Nordic Passport Union was one of the key elements in Nordic cooperation, and all the Nordic governments took the view that their citizens would not accept the end of freedom of movement between the Nordic countries without passports, which they had enjoyed for 40 years. Taking this consideration into account, the Nordic prime ministers stated a policy that envisaged the development of the Nordic Passport Union within the framework of Schengen. There were three possible lines of development at this point. First, the Nordic countries could have

\footnotetext{
${ }^{8}$ European Commission. Schengen, Borders and Visas. http://ec.europa.eu/dgs/home-affairs/what-we-do/policies/borders-and-visas/index_en.htm.

9 European Commission. Schengen Information System. http://ec.europa.eu/dgs/home-affairs/what-wedo/policies/borders-and-visas/schengen-information-system/index_en.htm.

10 August 3rd 2009. The Schengen area and cooperation. EUR-Lex. http://eur-lex.europa.eu/legalcontent/EN/TXT/?uri=URISERV\%3A133020.
} 
continued with the Nordic Passport Union and remained outside the Schengen area. Second, the Nordic Passport Union could have been abolished, and Sweden, Denmark, and Finland (as EU members) could have joined the Schengen scheme, with border inspection adopted between the Nordic countries. The third possibility, and the one that was in fact adopted, involved all the Nordic countries gaining access to the Schengen Convention (Anderson and Bort 2001, pp. 122-123).

Negotiations on access to the Convention by the Nordic countries proceeded smoothly and a cooperation agreement between Iceland and Norway and the Schengen member states was signed in Luxembourg on December 19, 1996, together with the membership agreements of Denmark, Finland, and Sweden. However, as a result of the changes caused by the Amsterdam Treaty, Iceland and Norway had to renegotiate their membership of the scheme. Therefore, Iceland and Norway began negotiations with the Council on participation in the Schengen scheme in 1998. Iceland and Norway had two main aims. The first was that the two countries were to ensure that when it came to formulating new rules for the Schengen Area, Iceland, and Norway would retain the same level of influence that they had had under the cooperation agreement of 1996, which expressly stated that Iceland and Norway were to play a full part in the implementation and formulation of Schengen rules in all fields, with the exception that they would not participate in voting. The second aim was that no monitoring function over the two countries' implementation of the Convention would be exercised by international institutions unless Iceland and Norway themselves were involved in such institutions in a manner at least comparable to its involvement in the institutions of the European Economic Area (EEA). The two aims were secured in the agreement on participation by Norway and Iceland in the implementation, application and development of the Schengen acquis, which was concluded late in 1998 and signed in Brussels on May 18, 1999. Thus, Iceland and Norway became 'associated Schengen states.' Switzerland also joined as 'associated Schengen state' later.

A special committee, the mixed committee, was established. Its function under the participation agreement of May 18, 1999 was to discuss all matters arising that fall under the scope of the Convention. Associated states do not participate in voting, when this takes place; the two states, therefore, take independent decisions in each individual instance concerning the approval of additions to the acquis. If they do not accept new rules, this entails the termination of the agreement, following the conciliation process provided for in the agreement itself. No independent supervisory or judicial system was established for Iceland and Norway.

\subsection{New Schengen State}

In 2004, 2007, and 2013, the EU has witnessed three enlargements which welcome 13 new member states into the union. ${ }^{11}$ However, these new member states do not become Schengen states automatically. Instead, they have to agree with all the articles in Schengen Agreement which has been incorporated into the EU framework as well as prepare to meet the preconditions which were mentioned in the first part. After their

\footnotetext{
${ }^{11}$ European Commission. Enlargement: from 6 to 28 members. http://ec.europa.eu/enlargement/policy/ from-6-to-28-members/index_en.htm.
} 
EU membership comes into force, they still need to be evaluated by the Schengen headquarters to check whether they are qualified to become a Schengen State (Rees 2011). For example, have they prepared to abolish all the border controls with other Schengen neighbor countries? Are they qualified to issue Schengen visas? Has their border system been connected to the SIS? Only with agreement from all the current Schengen states can the candidate states can be accepted as new Schengen states and their territories become part of the Schengen Area.

In 2004, ten countries joined the EU, most of which are Eastern European countries. Nine of them have been officially integrated into the Schengen Area, with the exception of Cyprus. According to the European Commission, Cyprus is "enjoying a temporary derogation from joining the Schengen Area" and is "currently carrying out preparatory activities to integrate into the SIS." 12

Bulgaria and Romania joined in 2007 and Croatia in 2014. All of these three new EU member states are still candidate Schengen states. They are working on preparation to meet all the conditions of the Schengen Agreement. Romania and Bulgaria have not yet been recognized by the European Commission as having

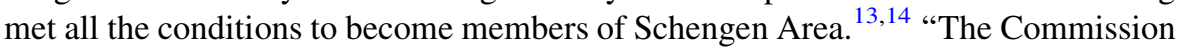
maintains its full support for Bulgaria's and Romania's accession to the Schengen area," $15,16,17$ and Croatia is more advanced in the entry process to become Schengen member. In March 2015, Croatia has officially declared its readiness for Schengen evaluation with a view to lifting control at the internal borders. ${ }^{18}$

For the nine new Schengen states, they have changed their visa regulations and policies according to the Schengen Agreement, which is stricter than their previous

\footnotetext{
12 European Commission. Schengen Information System. http://ec.europa.eu/dgs/home-affairs/what-wedo/policies/borders-and-visas/schengen-information-system/index_en.htm.

13 2015. Communication from the Commission to the European Parliament and the Council-Seventh Biannual Report on the Functioning of the Schengen Area (1 November 2014-30 April 2015). European Commission. http://ec.europa.eu/dgs/home-affairs/e-library/documents/policies/borders-and-visas/schengen/ docs/seventh_biannual_report_on_the_functioning_of_the_schengen_area_en.pdf.

14 2015. Communication from the Commission to the European Parliament and the Council—Eighth Biannual Report on the Functioning of the Schengen Area (1 May-10 December 2015). European Commission. http://ec.europa.eu/dgs/home-affairs/e-library/documents/policies/borders-and-visas/schengen/ docs/eighth_biannual_report_on_the_functioning_of_the_schengen_area_en.pdf.

15 2015. Communication from the Commission to the European Parliament and the Council - Seventh Biannual Report on the Functioning of the Schengen Area (1 November 2014-30 April 2015). European Commission. http://ec.europa.eu/dgs/home-affairs/e-library/documents/policies/borders-and-visas/schengen/ docs/seventh_biannual_report_on_the_functioning_of_the_schengen_area_en.pdf.

16 2015. Communication from the Commission to the European Parliament and the Council—Eighth Biannual Report on the Functioning of the Schengen Area (1 May-10 December 2015). European Commission. http://ec.europa.eu/dgs/home-affairs/e-library/documents/policies/borders-and-visas/schengen/ docs/eighth_biannual_report_on_the_functioning_of_the_schengen_area_en.pdf.

17 2016. Lack of visa reciprocity with the US, Canada and Brunei: European Commission assesses state of play and discusses next steps. European Commission. http://europa.eu/rapid/press-release_IP-16-1345_ en.htm.

18 2015. Communication from the Commission to the European Parliament and the Council-Seventh Biannual Report on the Functioning of the Schengen Area (November 1, 2014-April 30, 2015). European Commission. http://ec.europa.eu/dgs/home-affairs/e-library/documents/policies/borders-and-visas/schengen/ docs/seventh_biannual_report_on_the_functioning_of_the_schengen_area_en.pdf.
} 
visa policies, and started to issue uniform Schengen visas to applicants outside the Schengen Area. We can make a comparison between Hungary's visa policies toward Chinese visitors with Ordinary Passport for Public Affairs before and after their becoming New Schengen State (Table 2). ${ }^{19}$

Before issuing a Schengen visa to an applicant, the embassy needs to report all the information of the applicant to the Hungarian Immigration Office in Budapest, after which the information will be reported to the Schengen headquarters in Brussels for recording, and the SIS for screening, to ensure that the applicant as well as the inviter have a good credit record. Therefore, this extends the waiting time to get a Schengen visa for Chinese applicants to almost three times the previous waiting time. Change of visa policies also happened in Poland, the Czech Republic, and other new Schengen states. However, France and Germany do not need to report Chinese applicant's information to the Schengen headquarters for record. In addition, their embassies or consulates can issue short-term entry Schengen visas directly in less than a week as well as five-year visa for frequent travelers.

\subsection{Semi-Schengen State}

Both the UK and the Republic of Ireland are EU member states, but they have very little interest in joining the Schengen Area. They still remain the only two EU member states outside the Schengen Area; therefore, most articles in the Schengen Agreement do not apply to them. They maintain border controls with Schengen states as well as issue their own visas to visitors outside the EU.

However, although they are not Schengen states, the Amsterdam Treaty promises the possibility for them to become semi-Schengen states. When the Schengen acquis was incorporated into the EU framework, Ireland and the UK obtained an opt-out from the part of the treaty. Under the relevant protocol, Ireland and the UK may request to participate in aspects of the Schengen acquis, but this is subject to the approval of the Schengen states. The UK formally applied in 1999 to cooperate with the Schengen states in asylum, migration, and anti-crime relating to Police Security and Judicial Cooperation which were approved by the Council of the European Union on May 29, 2000. Ireland applied in 2000 with the same request as the UK and got approval in 2002. Later, both countries connected to the SIS to get more data and information to enhance border controls. ${ }^{20,21}$

The reasons why these two countries are reluctant to join the Schengen Area are different. $^{22}$ For the UK, it has concerns about the consequences of becoming a Schengen State which may hurt its independence and management of its

\footnotetext{
${ }^{19}$ Visa Types. Hungary Consulate General in Shanghai. http://shanghai.hungary-china.com/index. php?id=91.

20 2000. Council Decision (2000/365/EC) of May 29, 2000 concerning the request of the United Kingdom of Great Britain and Northern Ireland to take part in some of the provisions of the Schengen acquis. European Council.

21 2004. Council Decision (2004/926/EC) of December 22, 2004 on the putting into effect of parts of the Schengen acquis by the United Kingdom of Great Britain and Northern Ireland. European Council.

22 2007. Evaluating Schengen. Royal United Services Institute (RUSI). https://rusi.org/publication/ evaluating-schengen.
} 
Table 2 Hungary visa policy toward Chinese applicant with ordinary passport for public affairs Source: Hungary Consulate General in Shanghai

\begin{tabular}{|c|c|c|}
\hline $\begin{array}{l}\text { Requirements } \\
\text { and policies }\end{array}$ & Before joining Schengen Area & After joining Schengen Area \\
\hline Days to get visa & 7 days & 20 days \\
\hline Invitation letter & $\begin{array}{l}\text { Original invitation letter from } \\
\text { Hungarian inviter or Hungarian } \\
\text { Immigration Office }\end{array}$ & $\begin{array}{l}\text { Original invitation letter from Hungarian } \\
\text { inviter or Hungarian Immigration Office } \\
\text { with inviter's seal }\end{array}$ \\
\hline Flight ticket & Copy of return flight ticket & $\begin{array}{l}\text { Copy of return ticket including all the flights } \\
\text { inside the Schengen Area }\end{array}$ \\
\hline Accommodation & None & $\begin{array}{l}\text { Copy of hotel booking information in Hungary } \\
\text { or all booking information during the trip if } \\
\text { visit other Schengen states }\end{array}$ \\
\hline Proof of & None & $\begin{array}{l}\text { Original certificate of deposit from a } \\
\text { recognized bank of the applicant (more than } \\
50,000 \mathrm{RMB} \text { ) }\end{array}$ \\
\hline Business license & $\begin{array}{l}\text { Copy of applicant's company's } \\
\text { business license by the Chinese } \\
\text { government }\end{array}$ & $\begin{array}{l}\text { Copy of applicant's company's business } \\
\text { license by the Chinese government, with } \\
\text { copy of English translation and company } \\
\text { seal }\end{array}$ \\
\hline Proof of trade & None & $\begin{array}{l}\text { Proof of bilateral trade information between } \\
\text { the Hungarian inviter and the applicant's } \\
\text { company, such as contract and letter of } \\
\text { intent }\end{array}$ \\
\hline Insurance & None & $\begin{array}{l}\text { Original statement of insurance during the trip } \\
\text { in Hungary }\end{array}$ \\
\hline
\end{tabular}

territory (Geddes 2005). The British government has always been reluctant to join any alliance or union initiated by any country on the European continent including the EU. Although during the Blair government, the British changed their attitude toward the EU and participated in EU affaire more actively, and the Cameron government has retreated and proposed a referendum to decide the relationship between the EU and the UK. During the last Scottish Independence Referendum, Scotland would join the EU and the Schengen Area after they had got independence in 2014. ${ }^{23}$ However, the result of the referendum for Scotland was to remain inside the UK. And even if they get independence from Westminster in the future, they have a long way to go to become a full EU member state and Schengen State. Therefore, currently, there seems no possibility for the UK to join the Schengen Area, since both the government and a large group of the British people are not in favor of it. For Ireland, the reason for opting out of Schengen Area is simpler: because the UK chooses to opt out and they want to maintain the Common Travel Area (CTA) with Britain. ${ }^{24}$ If Ireland joins the Schengen Area, visitors can travel from other Schengen states to Ireland and then enter the UK according to the current

\footnotetext{
${ }^{23}$ 2013. Scotland's Future. The Scottish Government. http://www.scotland.gov.uk/Publications/2013/11/ 9348/0.

${ }^{24}$ March 4, 2009. Could Ireland join Schengen? The Guardian. https://www.theguardian.com/ commentisfree/2009/mar/04/immigration-eu.
} 
CTA. Due to the refusal to join the Schengen by the British, it leaves the Irish no choice but to stay outside Schengen if they want to keep the CTA.

\section{United or Alienated?}

Grouping European countries according to their relationship with Schengen is still not enough to judge whether Schengen has united or alienated Europe. Further analysis is to be carried out from three perspectives: Schengen states, non-Schengen states, and states outside of Europe. We will use cases in each perspective to support the argument of 'imperfect integration'.

\subsection{Schengen States}

In the Schengen Area, some countries, such as France, Germany, and Spain, are big states, but more are small states such as the Netherlands, Belgium, and Luxembourg, both of which welcome the free movement of people and goods. Workers can find jobs abroad if there is better compensation and benefits which will on the one hand give full play to workers' abilities and on the other hand improve the working environment and payment in their own countries. University students can travel to other countries during vacations or even study as exchange students via the Erasmus program without applying for a visa. Businessmen travel from one city to another inside the Schengen Area more frequently to deal with clients and suppliers from all over Europe. This prosperity could not happen without Schengen.

Germany, as one of the five founding members, is a good example to show how Schengen states have benefited. Economically, Germany has a large population and territory and is world renowned for its advanced technologies in manufacturing, including automobiles, electrical equipment, and chemical engineering. These products can enjoy free movement to other Schengen states, which means that citizens can pay less to purchase the same product than before, when taxes and border controls were still valid. From the political side, Germany is becoming the geographical center of Europe due to the enlargements of both the EU and the Schengen Area. Although the EU and Schengen headquarters are located in Brussels, sometimes Germany can play a more important role to deal with urgent issues, such as the Ukraine crisis. Culturally, according to statistics, German people have high self-identification as European citizens. ${ }^{25}$ Since self-identification is one of the key determinants of successful European integration, the cultural effect of Schengen should not be neglected when we analyze.

From all economic, political, and cultural perspectives, Schengen states are satisfied with the current situation, and European integration is an obvious consequence. However, it is still too early to say that Schengen has united Europe. Other states should also be taken into consideration.

\footnotetext{
25 2012. European Citizenship Report, May 2012. European Commission. http://ec.europa.eu/public_ opinion/archives/eb/eb77/eb77_citizen_en.pdf.
} 


\subsection{Non-Schengen States}

Non-Schengen states can be further divided into two categories. One is the several non-Schengen EU states, such as Romania, Ireland, and the UK. Another one is those non-EU European countries, such as Serbia, Ukraine, and arguably Turkey.

Non-Schengen EU states are the minority compared with Schengen EU states in terms of population, territory, GDP, etc. Among these non-Schengen EU states, only Ireland and the UK chose to opt out, while others are waiting to join. It is apparent that the Irish and the British governments take a more conservative position toward Schengen as well as the EU. They have concerns about problems brought by Schengen. For example, after the 'Arab Spring' in North Africa in 2011, tensions between France and Italy over Schengen have appeared. In April 2011, France shuts its borders to trains carrying African migrants from Italy who were among 20,000 migrants from Tunisia and other North African countries and granted six-month residence permits by the Italian government. Italy accused France of violating Schengen, and both countries called for the Schengen rules on internal border controls to be modified. Later, the European Commission said the action was legal under Schengen but also amended the rules. ${ }^{26}$ This is not the only case of problems brought by Schengen. It is quite hard to convince the British government and people that these kinds of problems will not occur after the UK joins the Schengen Area. Therefore, it is not surprising to see that the self-identification of the British as European citizens is very low.

The situation for Cyprus, Romania, Bulgaria and Croatia is different from that of Britain and Ireland. These newly joined EU member states are waiting to become Schengen states. ${ }^{27}$ After their entry to the EU, they have been endeavoring to meet the criteria as Schengen states. However, the European Commission is not fully satisfied with their performance. Several EU and Schengen states have expressed their concerns including France and Germany. They are opposed to accepting these countries into the Schengen Area, because they have doubts about whether these countries can "police their own borders." ${ }^{28}$ Geographically, Romania, Bulgaria, and Croatia are close to Balkan countries, while Cyprus is neighbor to Turkey. People move across these borders frequently. If these countries become Schengen states and their external border control does not meet Schengen requirements, nonSchengen citizens can enter these countries and then freely enter the whole of Europe. This is why the EU is still encouraging these countries to improve their

\footnotetext{
${ }^{26}$ March 4, 2013. Q\&A: Schengen Agreement, 4 March 2013. BBC News. http://www.bbc.co.uk/news/ world-europe-13194723. Accessed May 4, 2014.

27 2011. Factsheet: What is Schengen? European Commission. http://europa.eu/rapid/press-release_ MEMO-11-608_en.htm?locale=en.

28 September 30, 2013. Now French foreign minister says Romania and Bulgaria should not be allowed into passport-free Schengen zone because of security fears. The Daily Mail. http://www.dailymail.co.uk/ news/article-2438646/French-Foreign-Minister-Romania-Bulgaria-allowed-Schengen-zone.html.
} 
border control. ${ }^{29,30,31}$ Even after the Commission recognizes that they have met all the criteria, the European Parliament will discuss and vote on their entry to the Schengen Area. Although these EU member states have been EU members for 3 or 4 years, they need to wait for several more years to become Schengen states. Yet, the people of these EU member states are disappointed about being rejected for free movement. They expected to enjoy free movement soon after their EU membership was issued. For citizens of Cyprus, Romania, Bulgaria, and Croatia, joining the EU does not mean free movement inside the Schengen Area. The gap between expectation and reality has caused low participation in EU affairs. A recent example is the European Parliament election in 2014. The turnouts in Romania, Bulgaria and Croatia were $32.44,35.84$, and $25.24 \%$, respectively, which are all lower than the EU average of $42.61 \%$. Cyprus's turnout has decreased significantly from $72.5 \%$ in 2004 to $43.97 \%$ in $2014 .^{32}$

For non-EU and non-Schengen states, the attraction of becoming an EU and Schengen member has never decreased. Turkey has been a candidate EU state for 4 years. Serbia started its application process recently. If the former Ukrainian President had not terminated the agreement with the EU, Ukraine would have become closer to the West. Although they are not in the EU or Schengen currently, they are looking forward to becoming members of the EU and afterwards automatically Schengen, and to getting involved in the European integration process, which they think they should not and could not remain outside of.

Therefore, the UK and Ireland have different views on Schengen with other nonSchengen EU states as well as those states that are neither Schengen nor EU members. They are not willing to be involved in the integration under the Schengen acquis, while others are desperate to enter the Schengen Area.

\subsection{States Outside Europe}

The success of European integration should not only be examined from the inside but also from the outside. Countries outside Europe should have a voice on this topic. Whether or not the US, Russia, China and many other countries regard Schengen as an acceleration of European integration reflects the achievements of Schengen within Europe and its influence worldwide.

\footnotetext{
29 2015. Communication from the Commission to the European Parliament and the Council— Seventh Biannual Report on the Functioning of the Schengen Area (November 1, 2014-April 30, 2015). European Commission. http://ec.europa.eu/dgs/home-affairs/e-library/documents/policies/borders-and-visas/schengen/ docs/seventh_biannual_report_on_the_functioning_of_the_schengen_area_en.pdf.

30 2015. Communication from the Commission to the European Parliament and the Council - Eighth Biannual Report on the Functioning of the Schengen Area (May 1, 2015-December 10, 2015). European Commission. http://ec.europa.eu/dgs/home-affairs/e-library/documents/policies/borders-and-visas/schengen/ docs/eighth_biannual_report_on_the_functioning_of_the_schengen_area_en.pdf

31 2016. Lack of visa reciprocity with the U.S., Canada and Brunei: European Commission assesses state of play and discusses next steps. http://europa.eu/rapid/press-release_IP-16-1345_en.htm. European Commission.

32 2014. Results of the 2014 European Elections. European Parliament. http://www.europarl.europa.eu/ elections2014-results/en/country-results-cy-2014.html.
} 
Different states treat countries outside Europe differently according to their authorities, which affect cognition of other countries. China is an example to show how the Schengen Area has alienated Europe. As has been mentioned above, new Schengen states and old Schengen states have different visa policies toward Chinese visitors. In addition, when Chinese visitors want to travel to the UK or Ireland, they need to apply for a separate British or Irish visa. If they want to visit both nonSchengen states and Schengen states, they need to apply for two visas at least, which takes more than 1 month minimum. It is not surprising to see that Chinese tourists prefer the Schengen visa to the UK and Ireland visas. ${ }^{33}$ Chinese scholars argue that the UK and Ireland will not join the Schengen visa scheme in the foreseeable future. However, the attractiveness of the Schengen visa will increase for Chinese visitors (Chen and Zhu 2010).

The British government realized the situation and tried to change it. When David Cameron, the then British Prime Minister, visited China in December 2013, he announced in Beijing and Shanghai that the British government would soon change the visa application procedure and requirements for Chinese visitors in order to let Chinese applicants get a UK visa in a shorter period. ${ }^{34}$ Also, the British government will negotiate with the Schengen headquarters and connect the UK visa to the Schengen visa which would enable Chinese visitors to go to the UK when they travel with a Schengen visa. He also made several key statements in China using phrases such as "as an EU member state" to show that the division between the British Islands and the European continent is not very fair, in order to attract Chinese visitors, because Chinese people always think Europe is one of their top travel destinations, but the UK as a non-Schengen State is not on the countries list when they make their travel plan. ${ }^{35}$

In response to the situation, the British government together with the Belgian government launched new visa arrangements for Chinese visitors in $2015 .^{36}$ Under the new service, Chinese visitors are able to submit visa applications for both countries (UK and Belgium) during a single visit to a UK visa application center in Beijing, Shanghai or Guangzhou. It is premature to evaluate the performance of this visa arrangement. However, the new visa arrangement shows that there is a need for the British government to attract more visitors through linking the British visa with the Schengen visa. The Schengen visa is much more attractive than the British visa. With a Schengen visa, Chinese tourists can visit Paris, Rome, Amsterdam, Berlin, Madrid, Copenhagen, Stockholm, and Geneva. While with the British visa, they can only travel inside Britain. By linking the British visa to the Schengen visa, the British government can foresee that more Chinese visitors will come to Britain.

\footnotetext{
33 February 4, 2011. Why the Chinese favor Schengen. Financial Times. https://next.ft.com/content/ 89fc95a0-2feb-11e0-a7c6-00144feabdc0.

34 December 3rd 2013. David Cameron eases China visa rules. The Telegraph. http://www.telegraph.co. uk/finance/china-business/10490692/David-Cameron-eases-China-visa-rules.html.

35 December 4, 2013. British Prime Minister David Cameron's China Visit. China Daily. http://www. chinadaily.com.cn/world/2013cameronvisitcn/.

3619 June 2015. Pilot scheme to streamline visa process for Chinese visitors. British Government. https:// www.gov.uk/government/news/pilot-scheme-to-streamline-visa-process-for-chinese-visitors.
} 
In sum, from the perspective of the Chinese, Schengen has united the European continent except those still outside the Schengen Area. However, it has alienated the two non-Schengen EU member states, the UK and Ireland, from the Schengen member states. This public opinion may or may not represent other countries, such as the US and Russia. However, at least we know how the world's largest population thinks.

\subsection{Imperfect Integration}

From the perspectives of Schengen states and states outside Europe, Schengen is no doubt a successful integration method. However, non-Schengen states cannot agree with them. Therefore, how shall we draw the conclusion? We may need to go back to the beginning of this article to recall the definition of 'European integration.' It should be reaffirmed that the term 'European integration' used here refers to the integration of the whole of Europe, not only the EU or Western European countries but all the European states ranging from Norway to Malta and from Ireland to Romania. Therefore, a real integration should involve or try to involve all these countries in the process. Under this standard, Schengen is not a complete integration, or an 'imperfect integration'.

Differentiation in integration leads to Schengen's imperfect integration. The integration should be a universal integration involving all the European states. However, the differentiation policy forced them to be divided into different groups, which made the 'imperfect integration' unavoidable. 'Imperfect integration' does not mean that Schengen is totally not working. In contrast, it has effectively united Europe politically, economically and culturally. At the same time, some countries have been alienated which makes the integration an imperfect one. Three points can be summarized to support the argument of 'imperfect integration'.

The first point is that Schengen states have deeply integrated with each other. This includes not only the EU states but also other countries outside the EU such as Iceland. More countries waiting to join Schengen are the best proof of Schengen's attraction and achievements. The majority of European countries have participated in the integration. The second point is that if one country cannot be fully involved in the process of European integration, then not only will this country be alienated, but also the integration will become imperfect. When facing the increasingly integrated Schengen states, states that chose to opt out will feel like an outsider and become more skeptical toward joining it. Their concerns about Schengen will not diminish and that is why the British government chooses to connect the UK visa to the Schengen visa rather than joining the Schengen Area. The third point is that integration always has two sides, external and internal, with equal importance. When we discuss European integration, we should also consider the reactions and feedbacks on the external side. Schengen has widely been regarded as one of the most successful integration methods in European history. However, the integration has a limit with respect to those countries which are reluctant to join. That is why the Chinese and many others think that Schengen is only Western Europen integration or European continental integration rather than a complete integration. 
Since 2014, new challenges for the Schengen Area have appeared. Due to wars and conflicts in Syria, Libya, Iraq, and other Middle Eastern and North African countries, millions of refugees have traveled to Europe, which has caused a great challenge to the Schengen Area. "The EU is facing an unprecedented migratory and refugee crisis following a sharp increase of mixed migratory flows since 2015."37 Most refugees have no Schengen visa. They choose to be smuggled by sea to Italy and Greece and go further to Germany or Sweden after entry to the Schengen Area. "This has led to severe difficulties in ensuring efficient external border control in accordance with Schengen acquis and in the reception and processing of migrants arriving". 38

In response to the refugee crisis, eight Schengen Area member states launched temporary internal border controls, including Germany, Denmark, Sweden, Austria, Hungary, Norway, Slovenia, etc. The Schengen Borders Code provides member states with the capability of temporarily reintroducing border controls at internal borders in the event that a serious threat to public policy or internal security has been established. ${ }^{39}$ Currently, five Schengen states still carry out border controls at internal borders, including Austria, Germany, Denmark, Sweden, and Norway. Their decisions are considered as "necessary and proportionate." 40 These countries will have internal border controls until November $2016 .^{41}$

These temporary internal border controls, although recognized by the EU as necessary and proportionate, have affected free movement within the Schengen Area (Groenendijk 2004). Temporary internal border controls have happened almost every year over the past decade due to various reasons. ${ }^{42}$ However, it is the first time that so many Schengen states have launched internal border control. In addition, several Schengen states have suspended free movement for almost 1 year,

\footnotetext{
37 2016. Council Implementing Decision Setting out a Recommendation for Temporary Internal Border Control in Exceptional Circumstances Putting the Overall Functioning of the Schengen Area at Risk. Council of the European Union. http://data.consilium.europa.eu/doc/document/ST-8835-2016-INIT/en/ pdf.

38 2016. Council Implementing Decision Setting out a Recommendation for Temporary Internal Border Control in Exceptional Circumstances Putting the Overall Functioning of the Schengen Area at Risk. Council of the European Union. http://data.consilium.europa.eu/doc/document/ST-8835-2016-INIT/en/ pdf.

39 Temporary Reintroduction of Border Control. European Commission Migration and Home Affairs. http://ec.europa.eu/dgs/home-affairs/what-we-do/policies/borders-and-visas/schengen/reintroductionborder-control/index_en.htm.

40 2016. Council Implementing Decision Setting out a Recommendation for Temporary Internal Border Control in Exceptional Circumstances Putting the Overall Functioning of the Schengen Area at Risk. Council of the European Union. http://data.consilium.europa.eu/doc/document/ST-8835-2016-INIT/en/ pdf.

41 2016. Member states' notifications of the temporary reintroduction of border control at internal borders pursuant to Article 25 et seq. of the Schengen Borders Code. European Commission. http://ec.europa.eu/ dgs/home-affairs/what-we-do/policies/borders-and-visas/schengen/reintroduction-border-control/docs/ ms_notifications_-_reintroduction_of_border_control_en.pdf.

42 2016. Member states' notifications of the temporary reintroduction of border control at internal borders pursuant to Article 25 et seq. of the Schengen Borders Code. European Commission. http://ec.europa.eu/ dgs/home-affairs/what-we-do/policies/borders-and-visas/schengen/reintroduction-border-control/docs/ms_ notifications_-_reintroduction_of_border_control_en.pdf.
} 
such as Denmark, Germany, and Austria. Trains from Austria to Germany need to be stopped for inspection by customs officers after entry into Germany. Free movement no longer exists in some parts of the Schengen Area, which is a challenge to the basic principle of the European Union and the Schengen Agreement.

The European Commission has called for all Schengen states to restore a fully functioning Schengen system by the end of 2016. "The objective would be to lift all internal border controls by December, so that there can be a return to a normally functioning Schengen area by the end of 2016". ${ }^{43}$ Whether a fully functioning Schengen area can be recovered is still too early to say. Yet, how to align policy amongst Schengen states remains a question.

A more recent challenge to Europe is the Brexit. The UK held a referendum on June 23, 2016 to decide whether the UK should remain or leave the EU. Leave won by 52 percent to 48 percent. However, Scotland and Northern Ireland both backed staying in the EU. Scotland backed Remain by 62 percent to 38 percent, while 55.8 percent of people in Northern Ireland voted Remain and 44.2 percent voted Leave. In London, 59.9 percent voters supported Remain and 40.1 percent backed Leave. ${ }^{44}$ The UK needs to negotiate its relations with the EU within two years after triggering Article 50 of the Lisbon Treaty. Although the UK chooses to opt out of the Schengen area, it still allows EU nationals to have free movement to the UK. Witnessing millions of refugees entering the Schengen area and terrorist attacks in France, Belgium, and Germany, the British people finally decided to leave the EU, in other words, a divorce with the Schengen area. As a non-Schengen EU member state, the UK has never been fully involved in European integration. And now, it prepares to say goodbye to the EU.

In short, the differentiation of Schengen results is an imperfect European integration. Although the Schengen states are generally satisfied and benefit from the Schengen Area, non-Schengen states have been alienated including both EU and non-EU states.

\section{Conclusion}

There is no doubt that the EU will pursue enlargement in the future toward its east border. Turkey has been a candidate state for more than a decade and Serbia also been added to the waiting list recently. Moreover, the Ukraine crisis has not been settled yet although the four parties, Ukraine, Russia, the US, and the EU, have met in Geneva twice and declared joint statements, which means that there is still a possibility of expanding the EU closer to Russia, Asia, and the Middle East.

However, what impact will these arguably foreseeable EU enlargements over the next several decades bring to the Schengen Area? Will the Schengen Area also be expanded eastward, since new EU member states should naturally accept the

\footnotetext{
43 2016. Back to Schengen: Commission proposes Roadmap for restoring fully functioning Schengen system. European Commission. http://europa.eu/rapid/press-release_IP-16-585_en.htm.

44 June 24, 2016. The UK's EU referendum: All you need to know. BBC News. http://www.bbc.com/ news/uk-politics-32810887.
} 
Schengen Agreement and prepare to become Schengen states? If the answer is 'Yes,' then this may cause non-Schengen EU states to become more alienated from the EU or even cause some original Schengen states to leave the Schengen Area. If the answer is 'No,' that kind of differentiated integration may cause discrimination toward those new member states which may damage the fundamental legitimacy and authority of the EU. In either path, the EU will meet challenges when new members join the Schengen Area. The best way for the EU to be well prepared for those challenges is to make consensus among European states, no matter whether they are EU member states or not. Only in this way can the outside see the solidarity of the Schengen Area and the possibility of developing the Area more successfully.

In conclusion, differentiation in Schengen integration has alienated some European states, especially those outside of the Schengen Area. The original plan of the Schengen was to unite Europe. It has achieved this goal in parts of Europe, but not the whole of Europe, and not even the whole EU. Thus, the integration of Schengen is imperfect. As an "imperfect integration," Schengen has undoubtedly united Europeans. If Schengen wants to become more successful and attractive in the future, or in other words to achieve a real European integration, it needs to involve the non-Schengen EU countries into the integration process during or even before its further eastward enlargement.

Acknowledgments The author is grateful to the European Commission Erasmus Mundus Joint Ph.D. School on "Globalization, the Europe and Multilateralism" and the China Scholarship Council for their financial support.

\section{References}

Anderson, Malcolm, and Eberhard Bort. 2001. The Frontier of the European Union. New York: Palgrave. Avery, Graham. 2012. EU Expansion and Wider Europe. In The European Union: How does it work?, 3rd ed, ed. Elizabeth Bomberg, John Peterson, and Richard Corbett, 161-184. Oxford: Oxford University Press.

Brady, Hugo. 2008. EU Migration Policy A-Z. London: Centre for European Reform.

Chen, Zhimin, and Juhua Zhu. 2010. Schengen Agreement and the Development of the EU's Common Visa Policy: Differentiation in Integration Process (Shengen xieding ji oumeng gongtong qianzheng zhengce de fazhan: yitihua jinchengzhong de chayihua jizhi). International Review 2010(2): 29-64.

Den Boer, Monica, and Laura Corrado. 1999. For the Record or Off the Record: Comments About the Incorporation of Schengen into the EU. European Journal of Migration and Law 1(4): 397-418.

De Zwaan, Jaap. 1998. Schengen and its corporation into the new treaty: the negotiating process. In Schengen Final Days? The Incorporation of Schengen into the New TEU, External Borders and Information System, ed. Monica den Boer. Maastricht: European Institute of Public Administration.

Eiriksson, Stefan. 2006. Deeply involved in the European project: Membership of Schengen. In Iceland and European Integration: On the Edge, ed. Baldur Thorhallsson, 50-58. London: Routledge.

Flores-Macias, Gustavo. 2007. Migration and Free Trade Agreement: Lessons from NAFTA and Perspectives for CAFTA-DR. In International Migration Law, ed. Ryszard Cholewinski, Richard Perruchoud, and Euan Macdonald, 147-162. New York: Cambridge University Press.

Geddes, Andrew. 2005. Getting the best of both worlds? Britain, the EU and migration policy, International Affairs 81(4): 734.

Groenendijk, Kees. 2004. Reinstatement of Controls at the Internal Borders of Europe: Why and Against Whom? European Law Journal 10(2): 153.

Keukeleire, Stephan, and Delreux Tom. 2014a. The External Dimension of Internal Policies. In The Foreign Policy of the European Union, ed. Stephan Keukeleire, and Delreux Tom, 222-241. Basingstoke: Palgrave Macmillan. 
Keukeleire, Stephan, and Delreux Tom. 2014b. EU Foreign Policy towards neighbourhood. In The Foreign Policy of the European Union, ed. Stephan Keukeleire, and Delreux Tom, 242-272. Basingstoke: Palgrave Macmillan.

Kolliker, Alkuin. 2001. Bringing together or Driving Apart the Union? Towards a Theory of Differentiated Integration. West European Politics 24(4): 125-151.

Kuijper, Pieter. 2000. Some legal problems associated with the communication of policy on visas, asylum and immigration under the Amsterdam Treaty and incorporation of the Schengen Acquis. Common Market Law Review 2: 345-366.

Rees, Wyn. 2011. The External Face of Internal Security. In International Relations and the European Union, 2nd ed, ed. Christopher Hill, and Michael Smith, 226-245. Oxford: Oxford University Press.

Smith, Karen E. 2011. Enlargement, the Neighbourhood, and European Order. In International Relations and the European Union, 2nd ed, ed. Christopher Hill, and Michael Smith, 299-323. Oxford: Oxford University Press.

Shichen Wang is a PhD Fellow at the Université libre de Bruxelles and University of Geneva. 